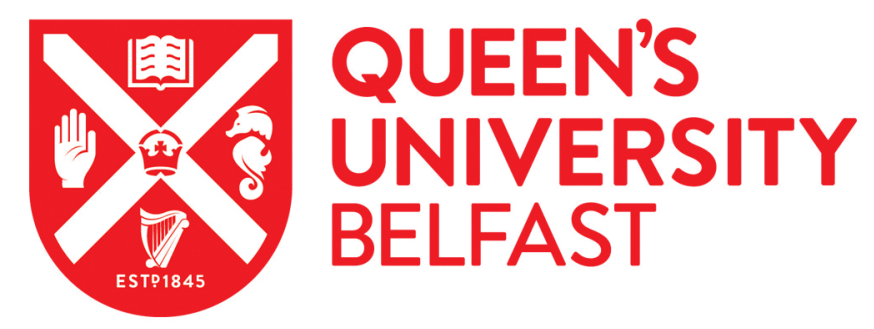

\title{
Agents of the nation-state or transformative intellectuals? Exploring the conflicting roles of civics teachers in Israel
}

Muff, A., \& Bekerman, Z. (2017). Agents of the nation-state or transformative intellectuals? Exploring the conflicting roles of civics teachers in Israel. Education, Citizenship and Social Justice.

https://doi.org/10.1177/1746197917743752

Published in:

Education, Citizenship and Social Justice

Document Version:

Peer reviewed version

Queen's University Belfast - Research Portal:

Link to publication record in Queen's University Belfast Research Portal

Publisher rights

Copyright 2017 SAGE. This work is made available online in accordance with the publisher's policies. Please refer to any applicable terms of use of the publisher.

\section{General rights}

Copyright for the publications made accessible via the Queen's University Belfast Research Portal is retained by the author(s) and / or other copyright owners and it is a condition of accessing these publications that users recognise and abide by the legal requirements associated with these rights.

Take down policy

The Research Portal is Queen's institutional repository that provides access to Queen's research output. Every effort has been made to ensure that content in the Research Portal does not infringe any person's rights, or applicable UK laws. If you discover content in the Research Portal that you believe breaches copyright or violates any law, please contact openaccess@qub.ac.uk. 


\section{AGENTS OF THE NATION STATE OR TRANSFORMATIVE \\ INTELLECTUALS? EXPLORING THE CONFLICTING ROLES OF CIVICS \\ TEACHERS IN ISRAEL}

Aline Muff and Zvi Bekerman

\section{INTRODUCTION}

A journalist has recently described citizenship education ${ }^{\mathrm{i}}$ as "Israel's hottest political football" (Sommer, 2016), which is quite an apt description in the face of the controversies that citizenship education in Israel has undergone in recent years. Two major controversies are worth mentioning. The first relates to the dismissal of the former civics coordinator of the Ministry of Education, Adar Cohen, who was perceived by members of the ministry as not being supportive enough of its ideology; a dismissal which has been viewed by educators, academics and politicians as reflecting the politicization of citizenship education (Nesher, 2012). While the old curriculum in civics promoted the idea of a balance between the concept of Israel as a Jewish and democratic state, the current Education Minister Naftali Bennet seeks to set a stronger focus on the study of Jewish identity across the curricula of different subjects. The education budget to fund Jewish education (NIS 56 million) exceeds about ten times the budget allocated to education for democracy (NIS 56 million) (Kashti, 2015). Additionally, the revised civics textbook ${ }^{\mathrm{ii}}$ as well as the pamphlet ${ }^{\mathrm{iii}}$ for the matriculation exam are the most recent examples of this shift to promote a nationalist-religious ideology that alienates Israel's non-Jewish minorities as well as more liberal and secular parts of the population (Skop, 2016a; Gravé-Lazi, 2016). 
The second major controversy relates to the public debate about whether civics teachers should be open about and express their political views when teaching or not. This controversy was sparked by the case of the civics teacher Adam Verta, who was reprimanded by the Ministry eventually losing his job because he expressed "extreme left" political views in class (Gravé-Lazi, 2014; Raved, 2014). While views that are critical towards the ideological foundations of the Israeli state came under scrutiny, it is important to note that teachers particularly in national-religious schools often take right-wing stances (Jerusalem Post, 2014). This exposes a sort of double-standard where political views in line with the dominant ideology are seen as more acceptable.

It has been argued that teachers in Israel act as role-models for the students and influence their students' political attitudes (Bar-Tal and Harel, 2002). How do civics teachers in Israel react to the political events mentioned above which increasingly impose a national-religious agenda on them? This is the main question that guides our present work. Following the work of other scholars (e.g. Swirski, 1999; Shafir and Peled, 2002; Al-Haj, 2005) in citizenship studies and education in Israel, we situate citizenship education within Gramsci's framework of cultural hegemony. The "new Zionist hegemony" (Rouhana and Sultany, 2003:19) represents a recent shift from a neoconservative towards an ethnic-nationalist agenda (Mustafa and Ghanem, 2009) that coexists with neoliberal trends in education in Israel (Agbaria, 2016). This agenda also dilutes other trends in educational policies such as multicultural education and human rights education (Al-Haj, 2002; Firer, 1998). Through this framework, we examine the role of the teachers as either agents of the nation-state, who follow the dominant political agenda or transformative intellectuals, who understand themselves as critical educators that challenge the existing hegemony (Giroux and McLaren, 1986). Our goal is to develop a better understanding of how civics teachers mediate between these conflicting roles in the face of the recent political developments. 


\section{TEACHERS TRAPPED IN BETWEEN HEGEMONIC AND COUNTER-}

\section{HEGEMONIC FORCES}

As Gramsci (1971/1929) has outlined in his work, education is one of those institutions that exert social control through cultural hegemony, transmitted through schools, systems of values, beliefs and practices that sustain the interests of the powerful groups. These particular values and beliefs that become established as "common-sense" (p. 323), are mediated through processes of socialization, such as education.

Citizenship education developed in the $19^{\text {th }}$ century as a subject to create a national consciousness, grounded on a natural association between the citizen-to-be and the nation (Heater 1999; Osler, 2011; Davies, Evans and Reid, 2005); asserting the nation-state as the major entity in demand of loyalty (Heater, 1990). The main goals of the national concept of citizenship education were the promotion of a common identity entrenched in a shared history as well as to foster patriotism and allegiance to the nation (Lawson and Scott, 2002; Heater, 1999).

School curricula such as citizenship, geography or history education promote national narratives, myths and heroes that shape a sense of belonging among their citizenry in the form of national and group identities (Anderson, 2006/1983; Phillips, 1998; Nash et al., 1998; Soysal, 2002). This usually happens at the expense of omitting histories, cultures and identities of minorities and marginalized groups in official curricula (Banks, 2008; Ladson-Billings, 2004; Osler and Vincent, 2002). Thus, citizenship education transmits a hegemonic ideology as Banks claims

'Mainstream citizenship education is grounded in mainstream knowledge and assumptions and reinforces the status quo and the dominant power relationships in society.' (Banks, 2009:313). 
However, in the last century, citizenship education has developed in different directions as well, incorporating the demands of social, political and cultural movements, educators and activists to comprise the areas of democratic education (e.g. Dewey 2004/1916; Gutman, 1987; Harber, 2004), human rights education (e.g. Osler and Starkey, 2005; Osler, 2008), peace education (e.g. Bar-Tal, 2002) and multicultural education (e.g. Banks, 2004; 2008). Educationalists call for a reimagining of citizenship education to create 'transformative citizens' (Banks, 2008) or 'deep citizens' (Clarke, 1996), who not only internalize democratic and moral principles, but also put them to action in order to challenge existing inequalities and promote social justice in their local and global community.

Critical educationalists (e.g. Freire, 1970; Giroux and McLaren, 1986) also demand that teachers should act as 'transformative intellectuals' (Giroux, 1988:127), who understand their teaching as a form of political struggle, to dismantle oppressive structures as well as to integrate the concern for the disadvantaged and oppressed in their teaching. They argue that transformative intellectuals should treat their students as critical agents, who learn to question how knowledge is produced and distributed. Following these demands, teachers should be granted the freedom to challenge the status quo in a society, to develop their students' critical thinking.

However, the understanding of teachers as 'transformative intellectuals' conflicts with the aims of more traditional forms of citizenship education, as outlined above. In contrast to the transformative intellectual's role to shape critical agents, this form of citizenship education focuses on the role of teachers as national agents (Dewey, 2004/1916), who encourage their students to develop strong identifications through narratives and memories of the nations (Banks, 2001; VanSledright, 2008). In this way, as Giroux and McLaren (1986) have concluded, teachers are constrained by nation-state ideologies as well as by the increasing submission of education to the 
logic of the market and economic modes of production, limiting their control and independence through mechanisms such as official centralized curricula and assessment policies.

\section{SETTING THE CONTEXT: CITIZENSHIP EDUCATION IN ISRAEL}

In Israel, the majority population is Jewish, consisting of diverse communities, ranging from secular to ultra-orthodox: Mizrachi or Sephardi Jews who emigrated from Eastern and North African regions make up about 50 percent and Ashkenazi Jews from European and North American descent represent about 30 percent of the Jewish population in Israel (Mizrachi, 2012). In addition, 20.7 percent $(1,730.000)$ of the total population is Palestinian ${ }^{\text {iv }}$, consisting of Muslims, Christians, Druze and Bedouins (Barakat, 1993; Lewin, 2012); and the remaining 4.4 percent $(364,000)$ are classified as "others" (non-Arab Christians, members of other religions and persons not classified by religion) (ICBS, 2015).

Recently, a range of policies and laws have been pushed forward to promote a nationalisticreligious agenda that sidelines democracy and diversity in Israel. As Mustafa and Ghanem (2010) claim, since its victory in 2009, the extreme right in Israel has consolidated its control, encompassing a general trend where the Israeli public, elite, academia and media has shifted further to the right, promoting policies that discriminate against Palestinians, supporting the construction of settlements in the West Bank as well as fostering the notion of Israel as an ethnicnational state.

Civic education has been a recent embodiment of this ideological shift. During the 1990s, a committee ${ }^{\mathrm{v}}$ was appointed to examine the state of the civics curriculum, leading to the formulation of a new curriculum in 1994 (Cohen, 2016). The new curriculum was then introduced in 2000 across two of the separate educational tracks in Israel ${ }^{\mathrm{vi}}$ - Jewish secular and Arab schools, while the two other educational tracks, state-religious and private schools enjoy certain autonomy 
and are exempted from the official curriculum. Until 2009, civics remained mainly taught from $10^{\text {th }}$ to $12^{\text {th }}$ grade, when many students are preparing for their matriculation exam (bagrut), but was also introduced as a compulsory subject for junior high schools in 2009. While it was assessed traditionally through a written exam, it was decided in 2008 to add an additional form of assessment, the implementation task (matlat bitzuah), where students identify an issue in their society, which they then research and suggest solutions for (Cohen, 2016).

In theory, this curriculum, which is currently based on the old textbook, deals with: the understanding of Israel as a Jewish and democratic state; universalistic aspects such as civil and human rights (Ichilov et al, 2005) underpinned by values of pluralism and tolerance (Ichilov, 2003).

The revised chapters of the textbook, which were published by the Ministry of Education in 2013, represent an attempt to shift the discourse away from the idea of Israel as a democratic state and towards the prioritization of the concept of Israel as a Jewish state. Pinson (2013) has closely examined the revised chapters and criticized four major points: First, the prioritization of the ethno-national discourse by presenting the concept of the Jewish ethnic state as the preferred and almost the exclusive model, while backgrounding other alternative conceptions that were presented in the previous textbook. Second, she criticizes the omission and almost complete neglect of the Arab-Palestinian minority's identity as a collective national group by portraying them as religious and cultural subgroups. Third, Pinson refers to the problematic presentation of liberal democracy as being consistent with the denial and limitation of minority rights, which, as she argues strengthens the ethno-national discourse that the book seeks to promote. Finally, she criticizes the pedagogical approach of the new book, which promotes and rewards memorization by asking closed-ended, and leading questions as opposed to encouraging critical thinking and 
discussion of controversial issues, dealing with the identity of the state and citizenship in Israel as in the previous book.

Despite these concerns raised by Pinson (2013), the new civics text book "To be citizens" was released in 2016 and subsequently criticized by academics, educators and activists mainly due to the lack of recognition of Palestinians as a collective group and their historical existence in the land (Skop, 2016a), as well as its emphasis on Jewish nationalism while it neglects the idea of shared citizenship in a Jewish and democratic state (Gravé-Lazi, 2016).

A range of scholars have outlined how the political culture as well as the educational institutions in Israel are spheres pervaded by hegemony. For example, the citizenship and history curricula promote a Jewish-Israeli narrative and identity (Bar-Tal, 1998; Firer, 1998; Al-Haj, 2005; Pinson, 2007b; 2013) while omitting Palestinian and Arab identities, culture and narratives (Pinson, 2007a, 2008; Agbaria, 2011; 2015). The lack of recognition of Palestinians in Israel as a collective with a common identity and heritage stands in stark contrast with the strong emphasis on the heritage of the Jewish people (Abu-Saad, 2004; Ichilov, 2008; Agbaria et al., 2015).

These problems have been recognized in the old as well as in the new civics textbook, yet the old textbook did offer a space to discuss alternative perspectives, narratives and identities, allowing students to develop their own stance after having examined different points of view. In contrast, the new textbook and pamphlet, which represent the ideology of the current government, seizes this space and fills it with their own right wing Zionist ideology, as the pamphlet even introduces set understandings of central political concepts instead of allowing a discourse about them (Skop, 2016c).

The role of the civics teacher is also conceptualized differently. The former curriculum allocated the teacher the role of a facilitator for democratic education and critical thinking; as it 
was underpinned by value-based goals such as respecting human rights, civil rights and participation in public issues as well as disposition goals such as the use of critical thinking skills, the development of complex ideas and tolerance towards different opinions (Bekerman, 2016).

Yet, the new textbook foresees the role of the teacher as a mediator of the dominant right wing Zionist ideology. In a way, the old curriculum in combination with the new textbook and pamphlet reflect two different perspectives on citizenship education: one is based on a dominant ethnic-national identity, loyalty and connection to the national ethos, whereas the other one refers to ideas of pluralism, the ability to think critically and independently as well as democratic and human rights education.

Through the discussion of our data, we seek to examine whether civics teachers struggle between the different demands by the curriculum and the textbook, their contradictory role as national agents and transformative intellectuals and their strategies to mediate between these roles. Our study focuses on the experience of Jewish-Israeli teachers, a group that is more privileged under the current hegemonic agenda, in contrast to Arab-Palestinian teachers, whose identity, history and collective rights are marginalized by the curriculum. Agbaria (2016) has demonstrated how Palestinian teachers partly seek to resist the curriculum by discussing alternative narratives as well as by dismantling its political agenda. Thus, we would like to elaborate on these findings by teasing out the ways how Jewish-Israeli teachers mediate their role.

\section{METHODOLOGY}

We used a grounded theory approach (Strauss and Corbin, 1998), as we did not embark on our study with a preconceived hypothesis, to explore the situation of Jewish-Israeli civic teachers. Between November 2013 and February 2014, we conducted twelve semi-structured interviews, which consisted of a few guiding questions about the interviewee's background, experiences and 
pedagogical approach in the classroom. We also asked teachers to reflect on how they perceived their personal views and beliefs influence their teaching, their view about the citizenship curriculum and its assessment, their understandings of democracy and the Jewish character of the state, as well as about their perceptions of major challenges. At all times, we allowed interviewees to choose the topics they wanted to focus on. The data collection was accompanied by an ongoing analytical process; whereby continual memo-writing supported the process of refining central concepts, which were followed-up by the interviewer throughout the interview process and eventually led to the formation of the themes we discuss in the analysis. This inductive approach (Charmaz, 2006) allowed us to develop our concepts from the empirical records, as they were mainly directed by what the interviewees considered as major aspects of their struggle as civic teachers (Marvasti, 2004).

The teachers age ranged from 22 to 64 years and they all taught citizenship education and related subjects at post-primary schools in Jerusalem and two schools in adjacent towns. While our focus was on the experience of Jewish-Israeli teachers, we selected teachers from different types of schools and from both Mizrachi and Ashkenazi backgrounds, to capture a broader picture of the experiences of civics teachers. Seven of the interviewees taught at Jewish-secular state schools, two at an integrated Palestinian-Jewish school, one at a school for Mizrachi students and the last two teachers taught at schools that promoted a religious ethos. The interviews were set in places of the interviewee's choice and each interview lasted between 60 and 90 minutes. All interviews were recorded and fully transcribed for repeated thematic analysis. In terms of the shortcomings of using a grounded theory approach, one might remark that our analysis relies heavily on the socially-constructed knowledge by the teachers (see Oliver, 2012); thus, it needs to be noted that 
our interpretation is strongly influenced by the teachers' own understanding of their social reality as this reality is reflected in their reports.

The interviews were conducted by the first author, who was considered an outsider, without any national, religious or cultural affiliation to any major group in Israel and we hoped that this outsider position would be an advantage in terms of the interviewees being more open to talk about sensitive issues such as political views on the conflict (see Colucci, 2008; Liamputtong, 2008). However, being an outside researcher can certainly have drawbacks, for example the use of English might have limited the ability of the interviewees to express their ideas as clearly as they would have in their native language $e^{\text {vii }}$. Yet, as the second author comes from a Jewish background and has lived in Israel for most of his life, we think this has brought an insider perspective into our interpretation as well.

\section{FINDINGS}

The analysis presents three different themes that outline different stages in which civics teachers find themselves in relation to the hegemonic ideology. We have named these three themes acceptance, resistance and transformation, reflecting a spectrum of stages among civic teachers ranging from being agents of the nation state, educators in resistance and finally to transformative intellectuals.

\section{ACCEPTANCE}

This section outlines two examples of how civic teachers find themselves in a state of acceptance, fulfilling their role as agents of the nation-state. The first example outlines that the nationalistic ideology, promoted by the dominant political culture as well as the education system, nourishes strong nationalistic emotions among students that causes some educators to avoid controversial 
issues. Our second example refers to the pressure imposed by the assessment policies that teachers experience, which leads some teachers to focus on optimizing their students' performance in the subject. We argue that they mediate what Gramsci (1971/1929) has termed "common-sense", by reproducing or failing to challenge the hegemonic ideology.

\section{AVOIDANCE OF CONTROVERSIAL ISSUES}

As civic education touches upon issues that are considered controversial in Israeli politics and society, such as the Israeli-Palestinian conflict or the situation of Arab-Palestinian citizens in Israel, teachers sometimes find themselves in heated debates with their students. Civics teacher Adam $^{\text {viii }}$ raises this issue

[The students] have zero common knowledge and ... they don't understand history, they're too much focused on feelings and not on facts. (...) there are emotions that are preventing them from hearing facts and understanding [them], "It can't be, it can't be that Israel is wrong".

Adam, as does Yael in a similar statement, describes how students develop strong patriotic feelings, which lead them to be protective about their country and prevent them from discussing critically their country's policies. Similarly, Itai recounts discussions with students that demonstrate the difficult balance between patriotism and principles such as equality and human rights

And then they bring the racism to class (...) theoretically we speak human rights, right; but in reality they really violate human rights all the time, as we speak in the class and they don't notice. We speak in the class about equality and [the students say] "Yeah we should be equal (...)". And then if we speak about the Arabs in Israel [they say] "No, no, no, I mean they shouldn't be equal" (...). Sometimes they just say that they shouldn't even exist. 
In the face of these attitudes by their students, which can turn discussions into heated emotionally-laden debates, civics teachers may struggle to address controversial issues in the classroom, as this statement by Noam demonstrates

It's very tricky too, because obviously in the classroom ... some of the stuff that is going on is very explosive, so to speak- ... you're risking blowing up the classroom and ... losing it completely. I try it very, very carefully, very tactfully. And sometimes ... it's just- I just- let it go...I don't refer to any situation, current affair, because I know it is just to ... it's too controversial and it's just too risky for me.

Noam's statement and his last sentence remind us of Adam Verta, the teacher who tried to challenge his student's expression of racism and criticized actions of the Israeli military, a subject also deemed to be very controversial in Israeli (Sheizaf, 2014). It appears that Noam feels constrained, not only by the strong views of his students, but also by the consequences that discussions about controversial issues could have for him as a teacher. Thus, while some teachers express concerns and anger about the nationalistic and racist views of their students, they do not always feel comfortable to challenge them, even if this goes against their own political beliefs and pedagogy. Related to this, Noam explains that the old curriculum promoted a "middle way" and was about "teaching civics in the least offensive way". However, this form of teaching the "middle way", while being more comfortable and less risky for the teacher, glosses over the controversial aspects. This issue has been also raised by Davies (2004) who argues that while we should not be naïve about the difficulties of entering a dialogue about sensitive issues in a conflict-ridden society, teachers may also be "guilty by omission" (p.114) if they do not create an atmosphere where these issues can be raised. By silencing the discourse about the controversial issues, such as the identity 
of the state or the conflict in their classroom, civics teachers act as national agents, since they avoid to question dominant views, current policies and thus the hegemonic (nationalistic) ideology.

\section{PRESSURE OF PERFORMANCE}

The need to prepare their students for the matriculation exam (bagrut) also leads teachers to conform to the role of agents of the nation-state. When asked about whether he has any doubts about the curriculum, civics teacher David backs off and explains that he is teaching according to the curriculum

I'm a good boy and I go with what they tell me, the plan. (...) You have to [follow the curriculum], because of the exam.

As David's statement shows, teachers are caught in a system of assessment that directs the focus of citizenship education towards the knowledge, which the Ministry of Education considers as relevant and as common-sense knowledge. The assessment policy pressures teachers to focus on the topics relevant to the matriculation exam and limits their independence to choose topics that they find important as well as opportunities to encourage critical thinking, discuss different perspectives, current political events and extra-curricular materials. As he is concerned about how his students will perform in the matriculation exam, Uri feels it is the teacher's responsibility to prepare the students for the exam

I cannot harm those children, because of the success of their future. ... I can talk to them all day long about actual things in the news and bring papers, but then they will be fucked up in the bagrut.

These examples illustrate how civics teachers feel inclined to follow the hegemonic ideology promoted by the state. Assessment policies and a patriotic, nationalistic curriculum 
promote a passive form of teaching and learning among teachers and students and facilitate what Bourdieu and Passeron (1990) have described as cultural reproduction. As our examples demonstrate, these reproduction processes are not only the result of teachers' unwillingness of engaging in counter-hegemonic discourses, but rather the result of constraints that the education system and the political culture impose on teachers.

\section{RESISTANCE}

While the section above outlined how teachers submit to the hegemony, our data also demonstrates that civics teachers engage in resistance, when they question the hegemonic logic of citizenship education in Israel. Our examples outline how teachers question the hegemonic notion of the Jewish and democratic state as well as how they redefine themselves as political teachers, opposing political trends that have recently questioned teachers' freedom to express their political views and to challenge the dominant nationalistic hegemony in front of their students

\section{DECONSTRUCTING THE NATION-STATE IDEOLOGY}

Civics teachers engage in a form of ideological critique (Giroux, 1983), which is a central task for transformative intellectuals, looking at how dominance is reproduced through practices. As an example of how teachers question the hegemonic logic; some teachers like Keren question the concept of the Jewish and democratic state and point to its inner tensions

It [democracy] is one of the most important things, but when you have the Jewish side, it's very hard to compromise between them. It's very strange to say that you are a democracy and you are religious inside, so it's [a] democracy only for the religion (...) It's a problem and it's a very big question. 
Similarly, for Oren the idea of a Jewish democratic state represents an "inner absurdum", which silences a discourse about the concepts' internal tensions, as he argues that Jewish citizens (particularly Mizrachim) are afraid to lose their privileges relative to the Arab-Palestinian citizens. Noam alludes to what the concept of a Jewish democratic state implies for citizenship in Israel. He declares Israeli citizenship as non-existent as it is dominated by ethnic-nationalism

There isn't such a thing as Israeli citizenship. It is only, you know, ethnic nationality. ... there is not such a thing as, you know civic identity or- civic politics in Israel- so, it's all dictated by (...) the particular group, you belong to (...).

Thus, in our interviews these teachers question the concept of a Jewish and democratic state. Noam does so when mentioning that ethnic-nationalism is not compatible with his idea of citizenship. From an educational perspective, the crux of their resistance is not necessarily that they oppose the ideological construct of the Jewish and democratic state, but rather that these teachers allow the counter-hegemonic space for a discourse about it that can challenge dominant beliefs and thus the hegemonic ideology of the state.

Another example of resistance raised by the teachers is their critique of the mostly onesided representation of historical narratives. As citizenship education is often closely related to history education (Sears and Hughes, 2006), in Israel, it serves to uphold the history and narrative of the Jewish state (Abu-Saad, 2004; Agbaria et al., 2015). Keren criticizes the curriculum's focus on Jewish history and the lack of space to discuss historical events from the perspective of the Palestinians, for whom the Nakba (the catastrophe the name given by Palestinians to the 1948 war) $^{\text {ix }}$ is an important event defining their national identity. 
When you are [teaching] ... history, you teach only the Jewish history and what happened in $48 .(\ldots)$ There is no place to speak about who was here, what was the real $[\ldots]$ situation here, and what is [the] Nakba.

Through her critique, Keren questions the hegemonic logic to teach students only the history from the mainstream perspective. Moreover, other teachers actively challenge the curriculum's focus on the mainstream narrative by introducing alternative perspectives into the classroom

I think that I'm trying to manipulate it [the curriculum] as much as I can. (...) I focus more and more on democracy and less on Jewish aspects of Israel, actually. (...) I'm trying to give different perspectives of problems, even though the curriculum doesn't tell me to do so, even though the curriculum tells me to bring only ... the Israeli (Jewish) side. (Itai)

Civics teachers Itai as well as Oren, who teaches his Jewish students about the Nakba despite the restrictions, both seek to counteract the tendency of the curriculum to emphasize only the Jewish aspects of Israel's history. They provide their students with alternative (Palestinian) perspectives and thus counter-knowledge that challenge the mainstream Zionist historical narrative and hegemony.

\section{BEING A POLITICAL TEACHER}

Another form of civic teachers' resistance is the expression of their political views in class. In our interviews, many teachers referred to Adam Verta and supported him by claiming that teachers should have the right to express their political views in class, even if they did not agree with Verta's political attitudes. All teachers stated that it is inevitable that their views will influence their teaching and Noam explains that also the curriculum pursues a certain political agenda. Ami, 
a rather patriotic teacher (he describes himself as Zionist-religious) and Dan, who is very critical of the state (he describes himself as non-religious, non-nationalist and cosmopolitan) both define civics teachers as political individuals in the context of Israel.

Constituting themselves as political individuals is an act of resistance, since it challenges the political elite's strategy to silence teachers with counter-hegemonic views. This strategy is exemplified by guidelines, published recently by the Ministry of Education that impose on teachers as well as external spokespersons invited to the classroom not to question or challenge the legitimacy of Israel as a Jewish and democratic state or of its institutions, such as the IDF (Ministry of Education, 2016).

While most of the teachers agree that they should not impose their views on students, they argue that teachers should be able to express their views and explain their reasons, especially when they are asked by their students about their opinions. As civics teacher Gil argues, it is important that students are confronted with different views and not only the dominant political agenda.

Thus, civics teachers outline how they find pockets of resistance by questioning and challenging the dominant discourse and redefining themselves as political teachers with the mission to expose their students to different perspectives. While part of their resistance only surfaces through their attitudes and opinions expressed in the interviews, some acts of resistance are described by teachers through their classroom practice. Thus, being an educator in resistance is not about imposing counter-hegemonic views on their students, but rather creating an atmosphere and opportunities to question, challenge and justify different views.

\section{TOWARDS TRANSFORMATION?}

Giroux (1988) outlines the preconditions for transformative possibilities that educators should employ: First, to make the classroom knowledge relevant to the students' lives; second, to 
make this knowledge problematic and to access it critically in order for students to question underlying oppressive structures such as racism; and finally, to create emancipatory knowledge ${ }^{\mathrm{x}}$ and experiences that enable students to transform oppressive structures. We will outline how teachers address the first two conditions of transformative possibilities and discuss whether these empower students with emancipatory knowledge to transform oppressive structures.

\section{COUNTER-DISCOURSES AND RELEVANT KNOWLEDGE}

One of the strategies used by civics teachers to empower their students by engaging them in "counter-discourses" (Giroux, 1997:250), to confront them with different views beyond the curriculum. Itai and Yael contrast learning the 'dry stuff' (Itai) for the matriculation exam, which is based on memorization of quite specific definitions with the discussion of current issues in their classroom that they see as more relevant to their students' lives. While the curriculum prescribes discussions about current issues (actualia), some teachers use this time in their lesson as a space for counter-discourses, by allowing their students to critically discuss recent policies as well as the dominant ideology and thus to challenge the hegemony and common-sense. Thus, these discussions, which are described as sometimes being initiated by the students themselves, provide them with knowledge beyond the textbook and the exams. Agbaria (2016) described this strategy also among Palestinian teachers in Israel, who employ the discussion of current events as a strategy to downplay the Zionist narrative and provide their students with alternative accounts.

Similarly, the new form of assessment for civics, the implementation task (matlat bitzuah) seems to allow possibilities for the students to deal with more relevant knowledge. While some teachers expressed concerns about how the project is implemented ${ }^{\mathrm{xi}}$, most teachers endorsed this new form of assessment and stated that it helps to improve students' writing and analytical skills 
as well as it encourages them to get engaged with social and political issues. Noam suggests that his students

see it as an opportunity to express themselves and to actually find something interesting that is interesting to them, not something that is dictated from above but that they actually find [interesting], that they are actually inspired by- and to get into it.

Despite being a form of assessment introduced by the government itself, the implementation task can potentially be a space for alternative learning against the traditional curriculum and its assessment, since students are not examined according to the dominant knowledge.

While discussions about current issues and the implementation task theoretically allow teachers and students to take civics beyond teaching for the test and mainstream knowledge mediated by dominant politics or by the textbook, it remains limited in practice and pervaded by the politics of assessment and the dominant (nationalistic) culture. As the statement of Uri demonstrated above, the hegemonic logic that considers relevant knowledge the subject matter that is tested in the matriculation exam, often prevails and leaves the teacher and students with insufficient time to discuss current issues. Additionally, as Noam has explained he often avoids discussing current issues, due to the strong reactions of his students and his anxiety that these discussions might have consequences for him. Thus, the potential for transformative education through counter-discourses remains limited.

\section{CRITICAL THINKING}

Another precondition for transformative thinking, the formation of a 'critical consciousness' (Giroux, 1983) among students, as a way of raising their awareness of oppressive systems, has also been addressed by the civics teachers. Yet, as the formation of critical thinking is also part of 
the official curriculum, also more conformist teachers like David draw on this as a goal of citizenship education

I think it makes them be more involved ... to understand the news, to think by themselves, not to say what their parents say, what their friends say, to think by themselves again.

While David demonstrates the consonance of following the curriculum and teaching critical thinking, other teachers go into a different direction and teach critical thinking by critically analysing the curriculum/textbook itself

[In] the first lessons we open the book and when we see that it's the Minister of Education, someone wrote it and decided to include some things in the [book], but obviously some things are not in the book. So, in each part we are putting on those critical glasses to see it from [the] point of view that why are things like they are ... a very philosophical, critical point of view. (...) Because it's also very political (...) deciding not to include the minorities in Israel, ok. It's a political decision! (Uri)

Uri describes how he encourages his students to think critically by discussing the political agenda of the textbook and why it covers certain topics while other topics are left aside. Through this critical examination of the textbook and its political agenda, Uri not only encourages his students to think critically, but also to question the views promoted by the textbook and the hidden interests of the political elite. These two examples show us how teaching critical thinking can be understood in different ways and while both ways are important, we argue that only Uri's approach is transformative, as he challenges the hegemonic logic. 
The following two statements from Gil and Oren outline how civic teachers find themselves within an internal conflict, triggered by the different demands of teaching for patriotism on the one hand and teaching critical thinking on the other.

I want them to love Israel, too. I don't want them to be bitter or hate and I don't want to make them leave or go or- but I want them to be critic[al]. (...) I want them to be connected to Israel, but I want them to know that there's a lot of things that we should solve and there's a lot of problems and there's a lot of complications. (Gil)

Similar to Gil, Oren is sensitive that when he engages his students in critical thinking (by teaching them about the Nakba) that this will alienate some of his Jewish students. However, Oren sees it as necessary to deal with these doubts as it is an important part of teaching about the conflict as well as promoting (transformative) critical thinking through an alternative historical narrative

I don't know what am I teaching them, it's critical thinking [on the] one hand and on the other hand it's taking a stand. And where does it put the Jewish students? I think that I can, I am holding this conflict and those doubts, so I'm holding it, I'm dealing with it and I'm bringing it also to the Jews to think about and I think in a good way.

Thus, while Gil constructs criticality primarily as addressing social and political issues in Israel, Oren adds another layer to the understanding of criticality through the examination of alternative perspectives and narratives. Oren teaches in an integrated Palestinian-Jewish school, which supports him to teach about the Nakba as part of its ethos of discussing conflictual historical narratives. The knowledge about alternative narratives is challenging the common-sense knowledge that the Jewish students grew up with and thus it is also emancipatory knowledge as it may encourage critical self-reflection and questioning of privilege and relations of power. The 
example of Oren shows that with the support of his school, he is able to challenge the hegemonic narrative, to encourage his students' to think critically and to be a political teacher.

According to the teachers' accounts about their classroom practice, some of them have adopted critical thinking as a key transformative strategy that enables students to learn about alternative views and to challenge the hegemonic ideology. However, the teachers report as well that it is difficult for their Jewish-Israeli students to be critical towards their country. Throughout our study we found that although many Jewish-Israeli teachers appear to be quite critical about their right-wing government, some teachers and their students, as reported by the teachers, have difficulty to see a connection between the exclusive nature of their state and the discrimination of its minorities or they see this discrimination as justified in order to protect the state's Jewish identity. This contradiction between the idea of a Jewish and democratic state shakes the core of the state's identity and is mirrored in the contradictory nature of citizenship education in Israel, which educates on the one hand for loyalty and patriotism and on the other hand for democratic attitudes and critical thinking. Yet, as Oren has demonstrated, in order to truly promote critical thinking as an educator, it is inevitable to engage in a process of critical self-reflection and questioning of mainstream values and narratives, which only a few teachers have demonstrated in our study.

\section{DISCUSSION}

The support of the school appears to be one major driver for teachers to become transformative intellectuals. The teachers who engage most in transformative teaching like Uri and Oren both work in schools, which grant them a lot of freedom to create their own curricula and the integrated school, according to Oren, promotes an ethos of inclusion of different narratives. 
Moreover, there seems to be another commonality between the teachers who seek to resist the hegemonic system, like Keren, Noam, Dan, Itai and Uri, as they all share a background in political science or sociology. In contrast, the teachers who do not seem to engage as much in the processes of resistance and transformation, have a background in history, Jewish philosophy or geography. In terms of their political views, we interviewed teachers across the spectrum from religiousnationalist to left-wing secular teachers and we found resistance also across the spectrum, even though the teachers who identified as religious-nationalist and Zionist tended more to accept the hegemonic logic that underpins citizenship education. Thus, while civics teachers' political affiliations impact on their decision to resist, even more important appears to be their own selfdefinition as political teachers. It seems that the civic teachers' educational background in subjects like political science and sociology prepare them better for the task to encourage critical thinking among their students as well as the support of their school to expand their teaching beyond the official curriculum.

\section{CONCLUSION}

Leaning on Gramsci's understanding, subordinate consent is quite a multifaceted mental state, a 'contradictory consciousness' (1971/1929:333), encompassing sentiments of resistance and acceptance at the same time. Thus, the teachers' response to citizenship education is complex, as they respond to the hegemonic structure of citizenship, sometimes by accepting or even reproducing the hegemonic discourse and sometimes in counter-hegemonic ways. Being aware of the inherent contradictions in citizenship education in Israel, teachers demonstrate their resistance to this "regime of representation" (Hall, 1990:225) in the citizenship curriculum by confronting their students with different perspectives, including Palestinian narratives and by stimulating their critical thinking. Yet, at the same time, all the civics teachers experience constraints imposed on 
them by the hegemonic ideology promoted by the state through curricula, the public political discourse as well as the neo-liberal logic of assessment that pressures teachers and students to focus on performance.

This contradictory role of the civics teacher, who is caught between the conflicting demands of citizenship education, which aims are to educate for loyalism and patriotism on the one hand and critical thinking, pluralism and transformation on the other, illustrates the crisis of citizenship education itself. The shift towards an ethnocentric and nationalistic form of citizenship education, which is currently under way in Israel, promotes a stronger identification with the Jewishness of the state, a Jewishness modeled after the understanding of the current political elite; while at the same time it alienates and silences groups with alternative identifications from citizenship. However, the interviewees have demonstrated through their own practice that some areas of citizenship education have potential to be spaces where counter-hegemony takes place, where students are confronted with alternative narratives and encouraged to critically question existing power relations.

In order to move towards more progressive forms of citizenship education that truly promote human rights, democracy and anti-racism as well as critical thinking, we need to empower teachers as transformative intellectuals and provide them with tools to employ their counterhegemonic strategies. Drawing on the experience of our interviewees, such tools can be: First, teacher training that prepares teachers for the demands of teaching (transformative) critical thinking, thus which equips them with teaching strategies to deal with controversial issues as well as a background in political education; second, institutional support to grant the teacher more freedom in developing her or his own curriculum and to allow a pedagogy that is more directed towards empowering students to investigate and develop critical thinking; and finally to strengthen 
alternative forms of assessment in citizenship education, such as the implementation task, which is not based on memorization but rather on developing students' research, expression and analytical skills and which makes them explore central political issues in their society.

While such an endeavor appears increasingly difficult in the current political climate in Israel, where right-wing forces seek to dismantle state and non-state democratic institutions, it can be still an effort that emerges at the margins of society, through counter-hegemonic organizations and individuals that promote transformative possibilities in education.

One of the shortcomings of our study is certainly the lack of students' perspectives in terms of reproducing and challenging the hegemonic discourse, since we have only relied on teachers' reports. Moreover, following our finding that institutional support is central for teachers to act as transformative educators, there is a need to further investigate the ministry's views regarding this. We think these are issues worth exploring through future research.

\section{NOTES}


i The term 'citizenship education' is used interchangeably with the terms of 'civic education' and 'civics' in this articles, referring to not only the official curriculum for the subject 'civics' but also the hidden curriculum ("the unspoken agenda in schools that socializes students into the dominant ideology" (Giroux and McLaren, 1986:309) and extra-curricular forms of citizenship education.

ii Some of the textbooks' authors asked for their names to be removed from the chapters as they accused officials of the Ministry to have altered the book afterwards to fit their ideology and not offering a textbook that addresses all civic students in Israel (Cheslow, 2016). At the time of writing, an opposition of academics, educators and activists has been formed that seeks to stop the use of the new textbook. While critics describe the textbook as being underpinned by the nationalist-religious ideology of the current government, government officials in response reject their criticism as politically motivated (Skop, 2016b).

iii A new pamphlet (machvan) for civics, which has been released by the Ministry of Education was harshly criticized by the High Court of Justice for issuing a set of definitions without prior discussion, such as the description of the Arab population as hostile towards the state and dividing them into different religious sects instead of a collective minority group, as well as the description of the Supreme Court as a subject of public controversy (Skop, 2016c).

iv Throughout this article the term 'Palestinian' or 'Arab-Palestinian' is used except for when direct quotes are used or when referring to official statements that use the alternative term Arabs. As Rabinowitz (1996) has argued, alternative labels such as 'Arab' or 'Israeli-Arab' are used deliberately by the majority population in Israel in order to omit the link between the political and national identity of 'Palestinians' and the land of Palestine, Falastin in Arabic.

${ }^{v}$ Informed by the work of the Shenhar and the Kremnizer committee, the Ministry of Education has published a new policy directive for civic education in 1994 and a common civics curriculum was implemented in Jewish schools in 2000 and in Arab schools in 2001 (Ichilov, 2008; Pinson, 2011).

vi The education system in Israel is split into four different educational tracks: state schools (mamlachti), Arab schools, state-religious (mamlachti-dati) and private schools (Iram and Shemida, 1998). A major debate around these different tracks is that while religious schools receive a high level of funding from the state, they also enjoy a high level of autonomy (Shamal, 2000), in contrast to state schools and Arab schools. This has led Arab-Palestinian academics, politicians and educators to demand the same level of autonomy for their schools in order to create curricula that teach Arab-Palestinian children about their history and culture (e.g. Jabareen, 1999 cited in Jabareen, 2006; Miller, 2015).

vii The interviewees were free to express terms and ideas in Hebrew, which were later translated. Some of the excerpts were edited to make them clearer and more coherent, while being careful not to alter the meaning and authenticity of the interviewees' accounts.

viii Interviewees' names were changed to ensure their anonymity.

ix The Nakba day marks a day of mourning for Palestinians, while it is mainly celebrated as Yom Ha'atzmaut, the national day of Israel's independence. In 2011, the Knesset has passed a bill that allows the ministry of finance to decrease or even to withhold and withdraw funding from institutions that commemorate the Nakba day as a day of mourning, following the rationale that the teaching of the Nakba would politicize Palestinian children, as it reminds them of the loss of their land (Peled-Elhanan, 2012).

× Habermas (1968) has defined emancipatory knowledge as a form of freedom that can be achieved through the power of self-reflection, leading to the development of a critical consciousness and liberating the individual from institutional, environmental and ideological forces.

xi Some teachers criticized that there is a lack of teacher training for the implementation task; another teacher complained that it does not encourage activism, as it is still a form of assessment.

\section{REFERENCES}

Abu-Saad I (2004) Separate and unequal: the role of the state educational system in maintaining the subordination of Israel's Palestinian Arab citizens. Social Identities 10(1): 101-127. 
Agbaria AK (2011) Civic Education for the Palestinians in Israel: Dilemmas and Challenges. In: Alexander HA, Pinson H and Yonah Y (eds) Citizenship, education, and social conflict: Israeli political education in global perspective. New York, London: Routledge, pp. 217-237.

Agbaria AK (2015) Arab civil society and education in Israel: The Arab Pedagogical Council as a contentious performance to achieve national recognition. Race Ethnicity and Education 18(5): $675-695$.

Agbaria, AK, Mustafa M, Jabareen YT (2015) 'In your face' democracy: education for belonging and its challenges in Israel. British Educational Research Journal 41 (1): 143-175.

Agbaria AK (2016) Ethno-National Politics of Citizenship Education in Israel and the CounterKnowledge of Palestinian Teachers. In: Banks JA, Suárez-Orozco M, Ben-Peretz M (eds) Global Migration, Diversity, and Civic Education- Improving Policy and Practice. New York: Columbia University Teachers College Press, pp.156-176.

Al-Haj M (2002): Multiculturalism in deeply divided societies: the Israeli case. International Journal of Intercultural Relations 26: 169-183.

Al-Haj M (2005): National Ethos, Multicultural Education, and the New History Textbooks in Israel. Curriculum Inquiry 35 (1): 47-71.

Anderson B (2006/1983) Imagined Communities: Reflections on the Origin and Spread of Nationalism. London: Verso.

Banks JA (1984) Multicultural education and its critics: Britain and the United States. The New Era 65: 58-65.

Banks JA (2001) Citizenship Education and Diversity: Implications for Teacher Education. Journal of Teacher Education 52(5): 5-16. 
Banks JA (2004) Teaching for Social Justice, Diversity, and Citizenship in a Global World. The Educational Forum 68(4): 296-305.

Banks JA (2008) Diversity, Group Identity, and Citizenship Education in a Global Age. Educational Researcher 37(3): 129-139.

Banks JA (2009) The Routledge International Companion to Multicultural Education. New York: Routledge.

Barakat H (1993) The Arab world: Society, culture and state. Berkeley: University of California Press.

Bar-On D (2008) The Others Within Us: Constructing Jewish-Israeli Identity: Cambridge University Press.

Bar-Tal D (1998) The Rocky Road Toward Peace: Beliefs on Conflict in Israeli Textbooks. Journal of Peace Research 35(6): 723-742.

Bar-Tal D (2002) The Elusive Nature of Peace Education. In: Salomon G, Nevo B (Ed.) Peace education: The concept, principles and practice in the world. Mahwah, New Jersey: Lawrence Erlbaum, pp.27-36.

Bar-Tal D and Harel AS (2002) Teachers as agents of political influence in the Israeli high schools. Teaching and Teacher Education 18(1): 121-134.

Bekerman Z (2016) Between Religious/Ethnic Epistemologies and the Development of Civic Identities in Western Education. In: Banks JA, Suárez-Orozco M, Ben-Peretz M (eds) Global Migration, Diversity, and Civic Education: Improving Policy and Practice. New York: Columbia University Teachers College Press.

Bourdieu P and Passeron J (1990) Reproduction in Education, Society and Culture. London: Sage. 
Central Bureau of Statistics (ICBS) (2013) PRESS RELEASE 65th Independence Day - More than 8 Million Residents in the State of Israel. Available at: http://www1.cbs.gov.il/www/hodaot2013n/11_13_097e.pdf (accessed 18 January 2013).

Charmaz K (2002) Qualitative Interviewing and Grounded Theory Analysis. In: Gubrium J and Holstein J (eds) Handbook of Interview Research: Context and Method, Thousand Oaks, California: Sage, pp. 675-694.

Charmaz K (2006) Constructing grounded theory: A practical guide through qualitative analysis. London: Sage.

Cheslow D (2016) Israeli educators battle government over textbook content, The Times of Israel, 13 Feburary. Available at: http://www.timesofisrael.com/israeli-educators-battle-governmentover-textbook-content/ (Accessed on 28 October 2016).

Clarke PB (1996) Deep Citizenship. London: Pluto Press.

Cohen A (2016) Navigating competing conceptions of civic education: lessons from three Israeli civics classrooms, Oxford Review of Education 42(4), 391-407.

Colucci E (2008) On the Use of Focus Groups in Cross-Cultural Research. In: Liamputtong P (eds) Doing Cross-Cultural Research: Ethical and Methodological Perspectives. Dordrecht: Springer, pp. 233-252.

Davies I, Evans M and Reid A (2005) Globalising Citizenship Education? A Critique of Global Education and Citizenship Education. British Journal of Citizenship Studies 53(1), 66-89.

Davies L (2004) Education and Conflict: Complexity and Chaos. London: RoutledgeFalmer.

Derrida J (1981/1972) Positions. Chicago: University of Chicago Press.

Dewey J (2004/1916) Democracy and Education. New York: Macmillan. 
Firer R (1998) Human Rights in History and Civics Textbooks: The Case of Israel. Curriculum Inquiry 28(2): 195-208.

Freire P (1970) Pedagogy of the Oppressed. New York: Continuum.

Ghanem A, Rouhana N and Yiftachel O (1998) Questioning 'Ethnic Democracy': A Response to Sammy Smooha. Israel Studies (2): 253.

Ghanem A (1998) State and minority in Israel: the case of ethnic state and the predicament of its minority. Ethnic and Racial Studies 21(3): 428-448.

Gilborn D (2004) Anti-Racism: From Policy to Praxis. In: Ladson-Billings G and Gilborn D (eds) The RoutledgeFalmer Reader in Multicultural Education. London: RoutledgeFalmer.

Giroux H (1983) Critical Theory and Educational Practice. In: Darder A, Baltodano M, Torres RD (EDS) The Critical Pedagogy Reader, New York: RoutledgeFalmer, pp. 27-56.

Giroux H and McLaren P (1986) Teacher Education and the Politics of Engagement: The Case for Democratic Schooling. Harvard Educational Review 56(5): 213-238.

Giroux H (1988) Teachers as Intellectuals: Toward a Critical Pedagogy of Learning. Westport: Bergin and Garvey.

Giroux H (1997) Pedagogy and the Politics of Hope: Theory, Culture, and Schooling. A Critical Reader. Boulder: Westview Press.

Gramsci A (1971/1929) Selections from the prison notebooks of Antonio Gramsci. New York: International Publishers.

Gravé-Lazi L (2014) ‘Extreme Left' high school teacher Adam Verta fired from ORT High School. Jerusalem Post, 25 May. Available at: http://www.jpost.com/National-News/Extreme-Lefthigh-school-teacher-Adam-Verta-fired-from-ORT-High-School-354320 (Accessed 6 December 2016). 
Gravé-Lazi L (2016) Critics say new Israeli civics textbook whitewashes and distorts reality. Jerusalem Post, 5 October. Retrieved from: http://www.jpost.com/Israel-News/Critics-say-newIsraeli-civics-textbook-whitewashes-and-distorts-reality-453570 (Accessed on 6 December 2016).

Gutman A (1987) Democratic Education. Princeton: Princeton University Press.

Habermas J (1968) Erkenntnis und Interesse. Framkfurt am Main: Suhrkamp.

Hall S (1990) Cultural Identity and Diaspora. In: Rutherford J (ed.) Identity: Community, culture, difference. London: Lawrence \& Wishart, pp. 222-237.

Hall S (2000) Who needs identity? In: Du Gay P, Evans J and Redman P (eds) Identity: A reader. London, Thousand Oaks, California: Sage, pp. 15-30.

Harber, C (2004) Schooling as violence: How schools harm pupils and societies. London: RoutledgeFalmer.

Heater D (1990) Citizenship: The Civic Ideal in World History, Politics and Education. Harlow: Longman.

Heater D (1999) What is Citizenship? Cambridge: Blackwell Publishers.

Iram Y and Schmida M (1998) The Education System of Israel. Westport: Greenwood Press.

Ichilov O (1991) Political Socialization and Schooling Effects among Israeli Adolescents. Comparative Education Review, 35(3): 430-446.

Ichilov O (2003) Teaching Civics in a Divided Society: The case of Israel. International Journal in Sociology of Education 13(3): 219-241.

Ichilov O, Salomon G and Inbar D (2005) Citizenship Education in Israel - A Jewish-Democratic State. Israel Affairs 11(2): 303-323. 
Ichilov O (2008) Citizenship Education in Israel: A contested Terrain. In: Arthur J, Davies I and Hahn C (eds) Sage Handbook of Education for Citizenship and Democracy, London: Sage, pp. 189-204.

Jabareen Y (2006) Law and Education Critical Perspectives on Arab Palestinian Education in Israel. American Behavioral Scientist 49(8):1052-1074.

Jerusalem Post (2014) Opinionated Teachers. Jerusalem Post, 2 March. Retrieved from: http://www.jpost.com/Opinion/Editorials/Opinionated-teachers-340260 (Accessed on 6 December 2016)

Kashti O (2015). Jewish and democratic - Yet ten times more the funding for the Jewish. Haaretz, January 17. Retrieved from http://www.haaretz.co.il/news/education/.premium-1.2540775 (Accessed on 06/12/16).

Ladson-Billings G (2004) Just what is Critical Race Theory and what's it doing in a nice field like education? In: Ladson-Billings G and Gilborn D (eds) The RoutledgeFalmer Reader in Multicultural Education. London: RoutledgeFalmer.

Ladson-Billings G (2005) Differing Concepts of Citizenship: Schools and Communities as Sites of Civic Development. In: Noddings N and Century B (eds) Educating Citizens for Global Awareness. New York: Teachers College Press, pp. 69-80.

Lawson D and Scott H (2002) Citizenship Education and the Curriculum. Westport: Ablex Publishing.

Lewin AC (2012) Marriage patterns among Palestinians in Israel. European Journal of Population 28(3): 359-380.

Liamputtong P (2008) Doing Cross-Cultural Research: Ethical and Methodological Perspectives. Dordrecht: Springer. 
Marvasti AB (2004) Qualitative research in Sociology: An Introduction. London: Sage.

Miller E (2015) MK wants Arab educators to get same autonomy as Orthodox Jewish teachers. Times of Israel, 21 June. Retrieved from: http:/www.timesofisrael.com/mk-wants-arab-educators-to-get-same-autonomy-as-orthodox-jewish-teachers/ (Accessed 12 November 2016).

Ministry of Education (2016) 9.2. Education for Democracy and Active Citizenship, published 11 December, 2016. Retrieved from http://cms.education.gov.il/EducationCMS/Applications/Mankal/EtsMedorim/9/9-2/HoraotKeva/K-2016-4-2-9-2-3.htm (Accessed 23 March 2017).

Mizrachi N (2012) On the mismatch between multicultural education and its subjects in the field. British Journal of Sociology of Education 33(2): 185-201.

Nash GB, Crabtree C and Dunn RE (1998) History on trial. New York: Knopf.

Nesher, T (2012) 'Israel Education Ministry fires civic studies coordinator attacked by right'. Haaretz, 6 August. Retrieved from: http://www.haaretz.com/print-edition/news/israel-education-ministry-fires-civics-studies-coordinator-attacked-by-right-1.456182 (Accessed 18 December 2016)

Mustafa M and Ghanem A (2010) The Empowering of the Israeli Extreme Right in the 18th Knesset Elections, Mediterranean Politics 15(1), 25-44.

Oliver C (2012) Critical Realist Grounded Theory: A New Approach for Social Work Research. British Journal of Social Work 42(2), 371-387.

Osler A (2008) Human Rights Education: The Foundation of Education for Democratic Citizenship in our Global Age. In: Arthur J, Davies I and Hahn C (Eds) 2008 - Sage Handbook of Education for Citizenship and Democracy, pp. 455-467. 
Osler A (2011) Teacher interpretations of citizenship education: national identity, cosmopolitan ideals, and political realities, Journal of Curriculum Studies, 43(1), 1-24.

Osler A and Vincent K (2002) Citizenship and the challenge of global education. Stoke on Trent: Trentham Books.

Osler A and Starkey H (2008) Teachers and Human Rights Education. London: Trentham Books.

Peled-Elhanan N (2012) Palestine in Israeli school books: Ideology and propaganda in education. London: I.B. Tauris.

Phillips R (1998) Contesting the Past, Constructing. British Journal of Educational Studies 46(1): $40-53$.

Pinson H (2007a) At the boundaries of citizenship: Palestinian Israeli citizens and the civic education curriculum. Oxford Review of Education 33(3): 331-348.

Pinson H (2007b) Inclusive Curriculum? Challenges to the Role of Civic Education in a Jewish and Democratic State. Curriculum Inquiry 37(4): 351-382.

Pinson H (2008) The excluded citizenship identity: Palestinian/Arab Israeli young people negotiating their political identities. British Journal of Sociology of Education 29(2): 201-212.

Pinson H (2013) From a Jewish and Democratic State to a Jewish State, Period: An Analysis of Modifications to the Civics Textbook "To Be A Citizen in Israel: A Jewish and Democratic State”. Retrieved from: http://www.acri.org.i1/he/wp-content/uploads/2013/12/Pinson-Reportsummary-en.pdf (Accessed 16 January 2016).

Raved A (2014) Hundreds protest against possible dismissal of 'leftist' teacher. Ynetnews, 25 January. Retrieved from: http://www.ynetnews.com/articles/0,7340,L-4480899,00.html (Accessed 18 December 2016). 
Rouhana N and Bar-Tal D (1998) Psychological Dynamics of Intractable Ethnonational Conflicts. The Israeli-Palestinian Case. American Psychologist 53(7): 761-770.

Said E (2003/1978) Orientalism. London: Routledge \& Kegan Paul Ltd.

Sears A and Hughes A (2006) Citizenship: Education or Indoctrination? Citizenship Teaching and Learning 2(1): 3-17.

Shafir G and Peled Y (2002) Being Israeli: The Dynamics of Multiple Citizenship. Cambridge: Cambridge University Press.

Shalom Chetrit S (2000) Mizrahi Politics in Israel: Between Integration and Alternative. Journal of Palestine Studies 29(4): 51-65.

Shamal S (2000) Cultural Shift: the case of Jewish religious education in Israel. British Journal of Sociology of Education 21(3): 401-417.

Sheizaf N (2014) On the Adam Verete affair and anti-democratic trends: Three notes, +972 magazine, 23 January. Retrieved from: https://972mag.com/on-the-adam-varete-affair-and-antidemocratic-trends-three-notes/86203/ (Accessed 20 December 2016).

Sleeter CE (1989) Multicultural Education as a form of resistance to oppression. The Journal of Education 171(3): 51-71.

Skop Y (2016a) Bennett's new civics book meets with Israeli-Arab furor. Haaretz, 12 May. Retrieved from: http://www.haaretz.com/israel-news/.premium-1.719053 (Accessed 6 December 2016).

Skop Y (2016b) Education Ministry brands critic of new Israeli civics textbook as leftist. Haaretz, 26 January. Retrieved from: http://www.haaretz.com/israel-news/.premium-1.699697 (Accessed 6 December 2016). 
Skop Y (2016c) Justice Joubran: Why are Arabs labeled as three different groups in new civics booklet? Haaretz, 27 July. Retrieved from: http://www.haaretz.com/israel-news/.premium1.733713 (Accessed 6 December 2016).

Smooha S (1997) Ethnic Democracy: Israel as an Archetype. Israel Studies 2(2): 198-241.

Smooha S (2002) The model of ethnic democracy: Israel as a Jewish and democratic state. Nations and Nationalism 8(4): 475-503.

Sommer AK (2016) How Civics Class Became Israel's Hottest Political Football. Haaretz, 27 January. Retrieved from: http://www.haaretz.com/israelnews/premium1.699897 (Accessed 11 April 2016).

Soysal YN (2002) Rethinking Nation State Identities in the New Europe: A Cross-National Study of School Curricula and Textbooks, Report from Economic and Social Research Council (ESRC). Essex: University of Essex.

Strauss A and Corbin J (1990) Basics of qualitative research: grounded theory procedures and techniques. Newbury Park, CA: Sage.

Swirski S (1999) Politics and Education in Israel: Comparisons with the United States. New York: Falmer Press.

VanSledright B (2008) Narratives of Nation-State, Historical Knowledge, and School History Education. Review of Research in Education 32(1): 109-146.

Yiftachel O (2006) Ethnocracy: Land and identity politics in Israel/Palestine. Philadelphia: University of Pennsylvania Press. 